\title{
A cost-benefit analysis of landfill mining and material recycling in China
}

\author{
Chuanbin Zhou*, Zhe Gong, Junsong Hu, Aixin Cao, Hanwen Liang
}

State Key Laboratory of Urban and Region Ecology, Research Center for Eco-Environmental Science, Chinese Academy of Sciences, 100085 Shuangqing Road 18, Haidian District, Beijing, China

\section{A R T I C L E I N F O}

\section{Article history:}

Received 17 February 2014

Accepted 30 September 2014

Available online 27 October 2014

\section{Keywords:}

Landfill mining

Material recycling

Cost-benefit analysis (CBA)

Economic feasibility

Net present value (NPV)

\begin{abstract}
A B S T R A C T
Landfill mining is an environmentally-friendly technology that combines the concepts of material recycling and sustainable waste management, and it has received a great deal of worldwide attention because of its significant environmental and economic potential in material recycling, energy recovery, land reclamation and pollution prevention. This work applied a cost-benefit analysis model for assessing the economic feasibility, which is important for promoting landfill mining. The model includes eight indicators of costs and nine indicators of benefits. Four landfill mining scenarios were designed and analyzed based on field data. The economic feasibility of landfill mining was then evaluated by the indicator of net present value (NPV). According to our case study of a typical old landfill mining project in China (Yingchun landfill), rental of excavation and hauling equipment, waste processing and material transportation were the top three costs of landfill mining, accounting for $88.2 \%$ of the total cost, and the average cost per unit of stored waste was 12.7 USD ton $^{-1}$. The top three benefits of landfill mining were electricity generation by incineration, land reclamation and recycling soil-like materials. The NPV analysis of the four different scenarios indicated that the Yingchun landfill mining project could obtain a net positive benefit varying from 1.92 million USD to 16.63 million USD. However, the NPV was sensitive to the mode of land reuse, the availability of energy recovery facilities and the possibility of obtaining financial support by avoiding post-closure care.
\end{abstract}

(c) 2014 Elsevier Ltd. All rights reserved.

\section{Introduction}

Landfills are widely used for municipal solid waste disposal due to the advantages of low capital and operational costs. The landfill rate in China is $73.4 \%$, with 547 urban landfills now in operation and approximately three billion ton of municipal solid waste disposed in landfills over the last 30 years (MOHURD, 2012). In the meantime, landfills also pose environmental and health threats to cities in terms of air pollution, groundwater contamination and health impacts on the densely settled urban population, hence remediation of old landfills is an urgent environmental issue accompanying rapid urbanization. (Singh et al., 2010; Svensson et al., 2010). As cities rapidly expand in recent years, many old landfills are now surrounded by built-up urban areas in China, and some landfill sites are even located at the centers of new developed urban areas (Krook et al., 2012). As a result, The Chinese National Twelfth Five Year Plan of Municipal Solid Waste Treatment and Management indicated a budget of 3.4 billion US Dollar/USD

\footnotetext{
* Corresponding author. Fax: +86 1062849147.

E-mail address: cbzhou@rcees.ac.cn (C. Zhou).
}

(21.1 billion China Yuan/CNY) for landfill eco-remediation projects in China from 2011 to 2015 (GOSCC, 2012).

Landfill mining was put forward as an approach to sustainable material management that combines municipal waste management and material recycling and has been adopted as a feasible technology for the ecological remediation of old landfills (Krook, 2010; Krook and Baas, 2013). According to Savage et al. (1993), landfill mining was first introduced in Israel in 1953 as a way to obtain fertilizers for orchards. Compared to other methods of landfill remediation, landfill mining has the potential to extract minerals and other natural resources from waste materials. After screening and separating the stored waste, metals and construction waste can be regenerated, soil-like materials can be applied as organic fertilizer to green spaces and gardens (Joseph et al., 2007), and materials with high calorific value can be treated by waste-to-energy (WtE) technologies (e.g. incineration, gasification, pyrolysis, plasma technologies, combinations) for energetic valorization and material recovery (Krook et al., 2012; Bosmans et al., 2013; Jones et al., 2013). Landfill mining is considered if the environmental pollution is urgent, land is scarce, or combustible waste treatment and energy recovery facilities are available (Zhao et al., 2007; Jain et al., 2013; Jones et al., 2013). Recent researches mostly focuse on the components and characteristics of stored waste and 


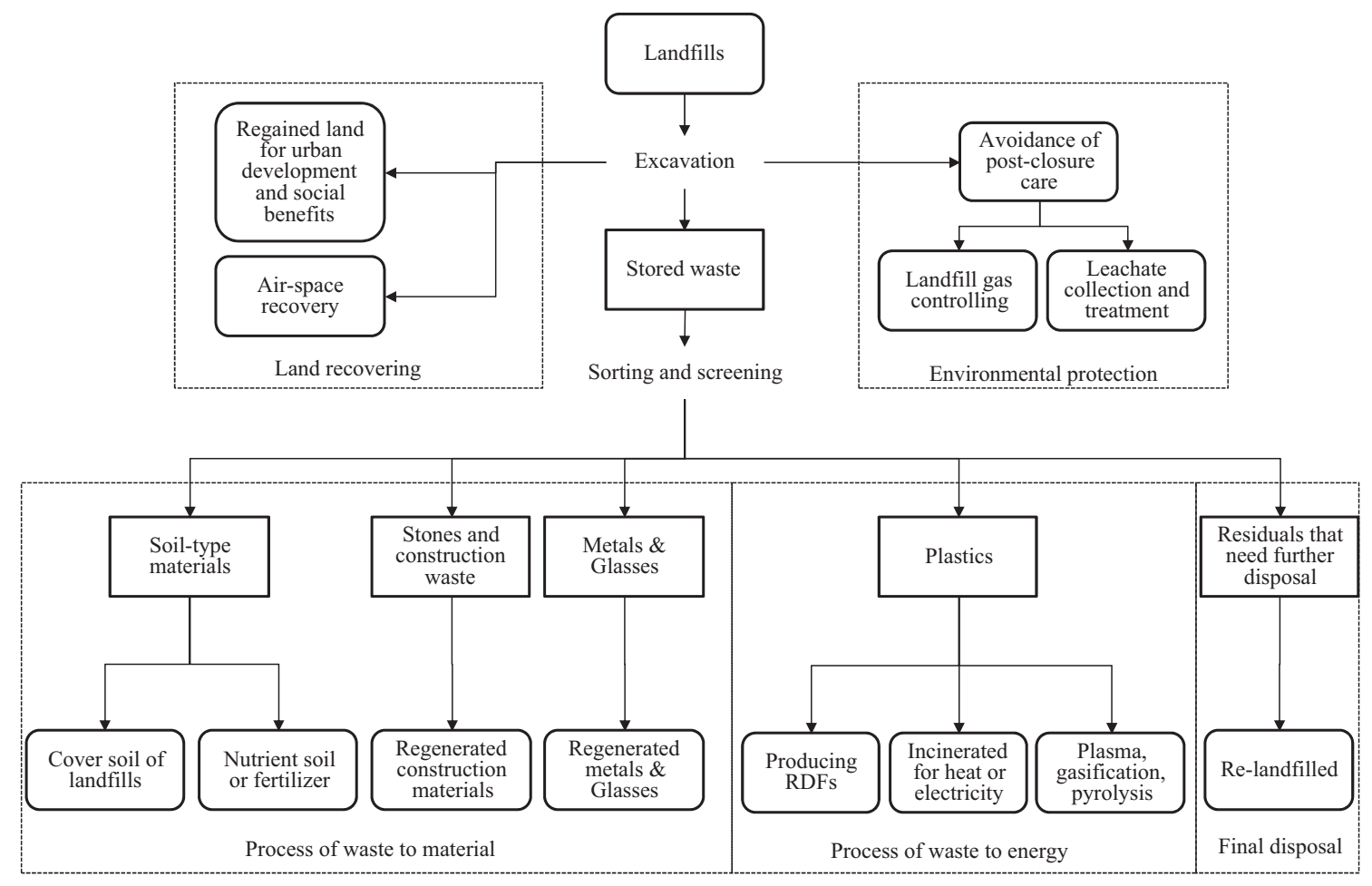

Fig. 1. Process of landfill mining and material-energy recovery.

waste-to-energy/material (WtE/M) technologies (Hull et al., 2005; Joseph et al., 2007; Quaghebeur et al., 2013; Bosmans et al., 2013).

Assessing the economic feasibility is an important issue when making decisions with respect to a landfill mining project, but only few studies have focused on the economic issue of landfill mining. The US-EPA (1997) developed a framework for assessing the potential economic benefits and the capital and operational costs of landfill mining projects. Van der Zee et al. (2004) put forward a stepwise method combining cost-benefit analysis (CBA) and multi criteria analysis (MCA) to help decision-makers select landfill mining projects with the best market opportunities. Followed by this methodology, Van Passel et al. (2013) built a CBA simulation tool considering the costs of landfill mining including excavation, sorting and pre-treatment, incineration and contingency, and the benefits including waste to material (WtM), waste to energy (WtE) and land reclamation. Moreover, contingent valuation method (CVM) was applied for assessing the social benefits of landfill mining and landfill rehabilitation (Ayalon et al., 2006; Marella and Raga, 2014). Previous studies have reported useful methodologies for assessing the economic feasibility of landfill mining, but the CBA model and the site- and facility-specific indicators require further discussion. In this research, we undertook a case study of a representative old landfill site that opened in the late 1980s and is now located in the urban area of Jingmen City, Hubei Province, China. The CBA model of landfill mining was applied and the economic feasibility was assessed based on field research and local investigation, and the landfill mining project was started from 2013 and is currently still on-going, guided by the present pre-activity study.

\section{Methodology}

\subsection{Framework of cost-benefit analysis for landfill mining}

Landfill mining is defined as a process of excavating a landfill using conventional surface mining technology to recover e.g., metals, glass, plastics, soils, and the land resource itself (Morelli, 1990).
Moreover, enhanced landfill mining (ELFM) is proposed and defined as the "the safe conditioning, excavation and integrated valorization of landfilled waste streams as both materials (Waste-to-Material, WtM) and energy (Waste-to-Energy, WtE), using innovative transformation technologies and respecting the most stringent social and ecological criteria", and emphasized the material and energy recovery (Krook et al., 2012; Jones et al., 2013). The process of landfill mining and material-energy recovery is shown in Fig. 1. Stored waste of the old landfill was excavated and then separated in various facilities: soil-like materials were separated by drum screening as the undersized material, and then oversized materials such as plastics, stones, and metals were separated by air classifiers and magnetic separators. Separated soil-like materials, stones and metals were recycled as organic fertilizers and substrates, regenerated construction materials and regenerated metals. The materials with high calorific value can be treated by incineration, gasification, pyrolysis, plasma technologies, producing residual derived fuels (RDFs) and combinations for energetic valorization and energy recovery, and in particular, the Gasplasma ${ }^{\mathrm{TM}} \mathrm{WtE}$ technology was mentioned as a sustainable approach of energetic waste valorization (Taylor et al., 2013; Bosmans et al., 2013). Land occupied by the landfills could be reclaimed for the usage of urban and industrial development or societal benefits (e.g. building a park on the landfill site), or the air-space could be recovered for a new landfill cell (Van Passel et al., 2013).

Economic indicators related to the processes of landfill mining and material-energy recovery were selected referring to the previous researches of Van der Zee et al. (2004) and the US-EPA (1997), and eight indicators of costs and nine indicators of benefits were taken into consideration (see Table 1). The site preparation includes the cost of the construction of a storm water prevention ditch, dirt prevention and cleaning, protective mesh and the temporary factory building. The costs and benefits calculation framework also considered the availability of local materialenergy recovery facilities. For example, enhanced thermal technologies (e.g., Gasplasma ${ }^{\mathrm{TM}}$, gasification and pyrolysis) can be 
Table 1

Framework of cost-benefit analysis for landfill mining.

\begin{tabular}{|c|c|c|c|}
\hline & Costs & & Benefits \\
\hline \multirow[t]{3}{*}{ Capital cost } & Site preparation (C1) & $\begin{array}{l}\text { Land and space } \\
\text { reclamation }\end{array}$ & Benefit of reclaimed land for urban development (B1) \\
\hline & $\begin{array}{l}\text { Rental or purchase of excavation and hauling } \\
\text { equipment }(\mathrm{C} 2)\end{array}$ & & Benefit of recovered air-spaces (B2) \\
\hline & $\begin{array}{l}\text { Rental or purchase of screening and sorting } \\
\text { equipment (C3) } \\
\text { Construction or expansion of materials handling } \\
\text { facilities (C4) }\end{array}$ & $\begin{array}{l}\text { Recyclable materials } \\
\text { recovery }\end{array}$ & $\begin{array}{l}\text { Recycling soil-type materials to organic fertilizer and substrate } \\
\text { (B3) } \\
\text { Recycling stones and construction waste to regenerate } \\
\text { construction materials (B4) }\end{array}$ \\
\hline \multirow{5}{*}{$\begin{array}{l}\text { Operational } \\
\text { cost }\end{array}$} & Pre-activity research cost (C5) & & Recycling metals and glasses (B5) \\
\hline & $\begin{array}{l}\text { Waste processing cost (excavation, screening and } \\
\text { sorting) (C6) }\end{array}$ & Energy recovery & Producing residue derived fuels (RDFs) from waste plastics (B6) \\
\hline & Cost of material transportation (C7) & & $\begin{array}{l}\text { Generating heat or electricity by incinerating waste plastics or } \\
\text { other combustibles (B7) }\end{array}$ \\
\hline & Waste final disposal cost (C8) & $\begin{array}{l}\text { Avoidance cost of post- } \\
\text { closure care }\end{array}$ & Avoidance of leachate collection and treatment (B8) \\
\hline & & & Avoidance of landfill gas emission (B9) \\
\hline
\end{tabular}

applied to convert the waste into high-value products, and may drastically promote the NPV value of the project. However, these enhanced thermal technologies are not full scale applied in China and as a consequence the data are not adequate in order to perform an economic analysis. Therefore the economic analysis of energy recovery was limited to incineration and producing RDFs.

\subsection{Scenario design and indicator}

According to previous researches, the approaches of land reclamation and energy recovery were the dominant factors that would determine the economic feasibility of landfill mining projects (Van Passel et al., 2013). Table 1 shows that the benefit calculation differs depending on the different approaches to land reclamation and energy recovery. If the land will be used for urban development or an industrial park after landfill mining, then the benefit of reclaimed land (B1) will be taken into consideration; otherwise, if the landfill is used as a new landfill cell after landfill mining, the benefit of recovered air-space (B2) will be calculated. The benefit of generating heat or electricity (B7) was taken into consideration if the city had incinerator and electricity generation facilities; otherwise, the combustible was supplied to companies as a raw material for residue derived fuels (RDFs) production (B6).

Four scenarios were designed according to the different modes of land reclamation and energy recovery to understand the cost-benefit balance of landfill mining projects. Scenario 1 (MAX), occupied land of the old landfill is reclaimed for urban and industrial development and the material with high calorific value is incinerated and then generated electricity; and total maximum benefit might be obtained in this scenario. Scenario 2 (MID-1), the air-space of the old landfill is recovered to be used as new landfill cell after landfill mining, and the material with high calorific value is incinerated and then generated electricity. Scenario 3 (MID-2), occupied land of the old landfill is reclaimed for urban and industrial development and the material with high calorific value is used as the raw material for producing RDFs. Scenario 4 (MIN), the air-space of the old landfill is recovered to be used as new landfill cell after landfill mining, and the material with high calorific value is used as the raw material for producing RDFs; and total minimum benefit might be obtained in this scenario.

To evaluate the economic feasibility and the market potential of landfill mining, the indicator of net present value (NPV) was adopted; the formula for NPV is shown as follows:

$N P V=\sum_{t=0}^{n} \frac{B_{t}-C_{t}}{\left(1+i_{s}\right)^{t}}$ where NPV is net present value; $t$ is the year; $B_{t}$ is the total benefit of the $t$ year; $C_{t}$ is the total cost of the $t$ year; $n$ is the calculated duration of the project in years; and $i_{s}$ is the social discount rate, suggested to be $8 \%$ for environmental facility construction projects by the Chinese government. $N P V>0$ means that the project will result in a positive benefit compared with current expectations (social discount rate); $N P V=0$ means that the project will just meet expectations; NPV $<0$ means that the benefits are lower than expected.

\subsection{Stepwise research and the data source}

The stepwise model suggested by Van der Zee et al. (2004) was adopted to obtain the data. Step 1: obtain position and distance data from a map; obtain basic landfill information from interviews with local government officials and companies who wanted to engage in this landfill mining project. Step 2: collect local plans and international references and analyze the quantity of stored waste using earthworks analysis software, and collect data on the boundary, area, elevation and depth of the studied landfill. Step 3: visit the landfill site and complete interviews with local stakeholders to determine the price of the regenerated materials \& RDFs, the local cost of renting different types of equipment, and the transportation distance and fees. Step 4: field research, including stored waste sampling and laboratory analysis. Using a drilling machine equipped with a $12 \mathrm{~cm}$ drill bit, we sampled the solid waste at grid locations $(100 \mathrm{~m} \times 100 \mathrm{~m})$. The number of obtained samples in each sampling location was not the same (maximum four samples in one sampling location, minimum one sample in one sampling location), because Yingchun landfill was constructed in a small valley, the landform of the original site was low in north and high in south, and the thickness of landfill layers was different for each sampling location. In total, twenty-two samples were collected from different landfill layers: the first layer $(0-6 \mathrm{~m}, 9$ samples), the second layer (6-12 $\mathrm{m}, 7$ samples), the third layer (12-18 m, 4 samples) and the fourth layer (18-24 m, 2 samples), and for each sample weighing around $50 \mathrm{~kg}$. The samples were screened $(10 \mathrm{~mm})$ and then were manually separated into soil, plastic, stone, textile, wood, metal, glass and other difficult to recognize items, and then the wet weight of different fractions for each sample was recorded.

\subsection{Description of the case}

The Yingchun municipal solid waste landfill in our case study is located in Jingmen, Hubei Province, central China. The landfill site 


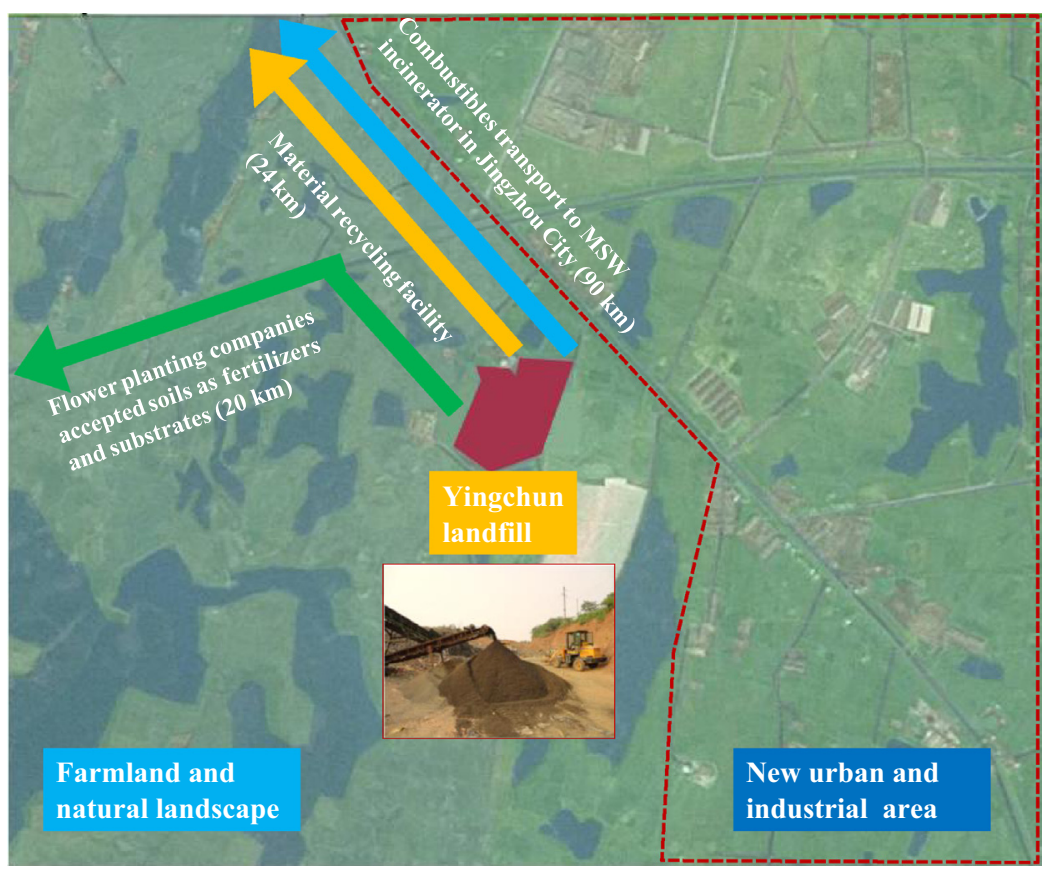

Fig. 2. The scheme of studied landfill mining project and the location of material-energy recovery facilities.

was constructed in 1989 and closed in 2004, and served 0.4 million inhabitants. It was a basic, unsanitary landfill covering an area of 11.3 ha. The site was built sloping northwards, giving it a dustpan-like appearance. The annual amount of disposed municipal solid waste increased from 36.5 thousand ton in 1989 to 154.8 thousand ton in 2004; the total amount of disposed municipal solid waste was 1470 thousand ton. The stored waste is still present in the landfill had been estimated to be approximately 501,000 ton $\left(551,000 \mathrm{~m}^{3}\right)$ by measuring the present elevations of the surface of landfill dump, compared it with the historic data of the base elevations, and calculated the stored wastes with grid method $(100 \mathrm{~m} \times 100 \mathrm{~m})$. Yingchun landfill was built up on clay (without liner) and a drainage system was also built for leachate collecting. Currently, this site produces approximately $80 \mathrm{~m}^{3}$ per day of leachate, accompanied by uncontrolled emissions of landfill gases. A pre-activity research (incl. characteristics of stored waste, waste output streams, economic and social aspects, etc.) of landfill mining was completed in 2012, and based on the results of pre-activity research, the landfill mining project was started from 2013 and still undergoing now. Fig. 2 shows the scheme of studied landfill mining project and the location of material-energy recovery facilities.

\section{Results and discussion}

\subsection{Characteristics of the studied landfill}

The average composition of disposed solid waste collected in the Yingchun landfill was analyzed (Fig. 3). Soil-like materials ranked first $(75.02 \%)$, followed by combustible materials (14.69\%) and then stone (8.26\%); other components only accounted for $2.03 \%$. According to the study of the composition, materials stored in the landfill included $375.9 \cdot 10^{3}$ ton of soil-like materials, $41.4 \cdot 10^{3}$ ton of stone, $3.2 \cdot 10^{3}$ ton of glasses, $2.1 \cdot 10^{3}$ ton of metals; $73.6 \cdot 10^{3}$ ton of material that could be used to recover energy; and $4.9 \cdot 10^{3}$ ton of waste that should be re-landfilled. The heat value was calculated considering the composition of combustible waste, and the average heat value was $23,564 \mathrm{~kJ} / \mathrm{kg}$. When the landfill mining project was completed, $551,000 \mathrm{~m}^{3}$ of air-space and 11.3 ha of land could be regained. The lab testing results revealed that the average heavy metal content of soil-like materials was below the limitations of the national standard of China. The heavy metal contents of soil-like materials were as follows: $\mathrm{Pb}$, $21.53 \pm 22.89 \mathrm{mg} \mathrm{kg}^{-1} ; \mathrm{Cd}, 0.14 \pm 0.11 \mathrm{mg} \mathrm{kg}^{-1} ; \mathrm{Cr}, 9.99 \pm 10.89$ $\mathrm{mg} \mathrm{kg}{ }^{-1}$; As, $29.61 \pm 9.57 \mathrm{mg} \mathrm{kg}^{-1} ; \mathrm{Hg}, 0.17 \pm 0.11 \mathrm{mg} \mathrm{kg}^{-1}$, while the Chinese National Standard for Urban Wastes for Agricultural Use (GB 8172-87) specifies the following upper limits for these heavy metals: As $\left(30 \mathrm{mg} \mathrm{kg}^{-1}\right), \mathrm{Pb}\left(100 \mathrm{mg} \mathrm{kg}^{-1}\right), \mathrm{Cd}\left(3 \mathrm{mg} \mathrm{kg}^{-1}\right), \mathrm{Cr}$ $\left(300 \mathrm{mg} \mathrm{kg}^{-1}\right), \mathrm{Hg}\left(5 \mathrm{mg} \mathrm{kg}^{-1}\right)$. It indicated that the soil-like materials (seems like natural black soils) could be applied as substrates or fertilizers to ornamental plants and garden plants (Zhao et al., 2007).

\subsection{Cost analysis}

The total cost of the Yingchun landfill mining project studied here was 6.34 million USD, with a capital cost of 3.04 million USD (47.9\%), an operational cost of 3.30 million USD (52.1\%), and an average cost of landfill mining of 12.7 USD ton $^{-1}$ (incl. capital cost and operational cost for total 501 thousand ton stored waste). Different capital and operational costs are shown in Fig. 4 and the detailed information used to calculate the costs is shown in Table A1. Among the eight categories of capital and operational costs: $\mathrm{C} 2>\mathrm{C} 6>\mathrm{C} 7>\mathrm{C} 3>\mathrm{C} 5>\mathrm{C} 4>\mathrm{C} 1>\mathrm{C} 8$. The top three costs of landfill mining, the cost of rental excavation and hauling equipment (2.53 million USD), waste processing (2.26 million USD) and material transportation ( 0.81 million USD) accounted for $88.2 \%$ of the total cost.

As the total cost of landfill mining depends on the local price of construction and rental facilities and equipment, the costs may be not the same from different landfill mining projects. According to previous research, the average cost of landfill mining projects was 2.94 to 11.5 USD ton $^{-1}$ before 2009 (IWCS, 2009). Our average cost of landfill mining was 12.7 USD ton $^{-1}$, a little higher than the previous researches in US. Several factors such as separation equipments, price of constructing materials and labor cost, environmental protection, inflation, etc. are responsible for the cost difference. In contrast to other solid waste treatment projects, the capital cost 


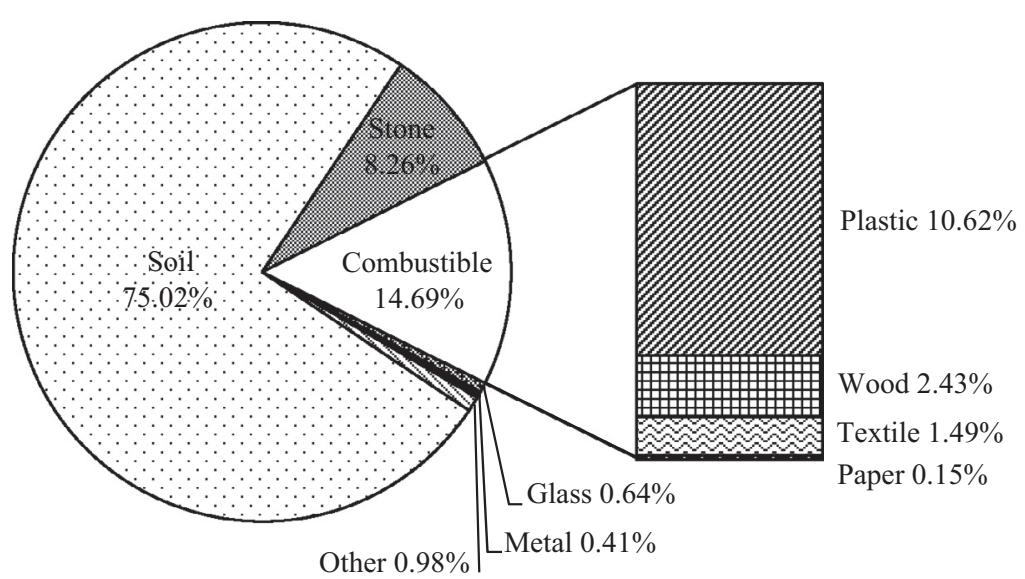

Fig. 3. Composition of stored solid waste in the Yingchun landfill in China (percent by wet weight).

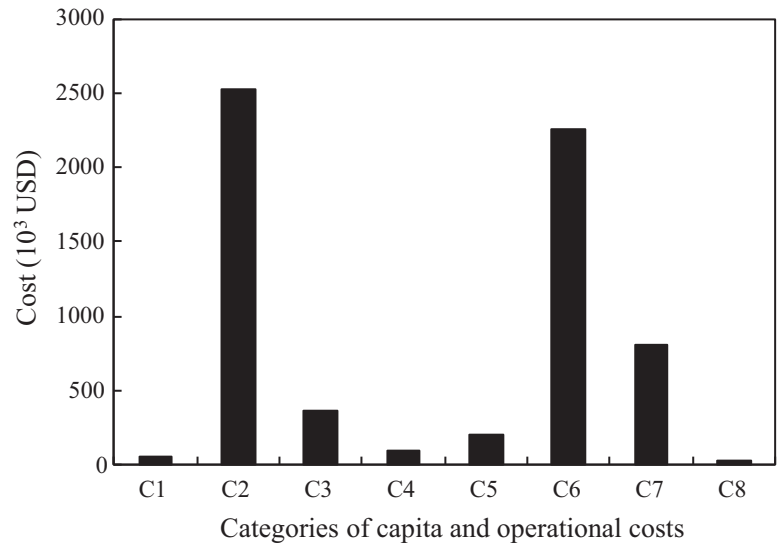

Fig. 4. Different categories of costs of landfill mining (C1: site preparation; $\mathrm{C} 2$ : rental excavation \& hauling equipment; C3: rental screening \& sorting equipment; C4: construction of materials handling facilities; C5: pre-activity research; C6: waste processing; C7: material transportation; C8: final disposal.).

was less than the operational cost in this landfill mining project. It was because the facilities and equipments were used temporarily in landfill mining, most of the capital costs were rental fees or capital asset discounts. The cost of renting mechanical separation equipment was not dominant among all the project costs, although it was the key technology of landfill mining processes. However, some extra costs may have been incurred in the landfill mining that was not included in our calculations. For example, additional costs include the cost of remediation of the bottom clay and groundwater, interruptions and disruptions due to inclement weather (heavy storms and snow), and unexpected problems (such as citizen protests) associated with hauling waste off-site to its ultimate destinations.

\subsection{Benefit analysis}

The maximum and minimum total benefits of the Yingchun landfill mining project studied here were 24.91 and 8.44 million USD based on different approaches to land reuse and energy recovery. The various benefits of landfill mining are shown in Fig. 5 and the detailed information used to calculate these benefits are shown in Table A2. Among the nine categories of benefits: B7 > B1 > B3 > B9 $>$ B2 $>$ B6 $>$ B8 $>$ B5 $>$ B4. The top three potential benefits, the benefit of generating electricity by incinerating combustibles (10.12 million USD), the benefit of land reclamation (8.23 million USD) and the benefit of recycling soil-like materials (3.64 million USD).

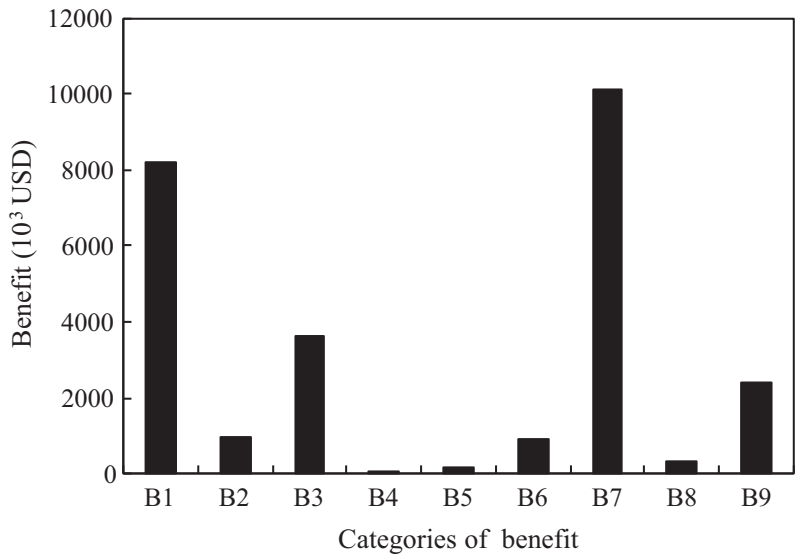

Fig. 5. Different categories of benefits of landfill mining (B1: benefit of regained lands; B2: benefit of recovered air-spaces; B3: recycling soil-like materials; B4: recycling stones and construction waste; B5: recycling metals and glasses; B6: producing RDFs; B7: generating electricity by incineration; B8: avoidance of leachate collection and treatment; B9: avoidance of landfill gas emission.).

The benefits were significantly different according to the different approaches to land reclamation and energy recovery: the benefit of land reclamation (B1) was 8.42 times that of the benefit of air-space recovery (B2), and the benefit of generating electricity by incineration (B7) was 11.4 times that of the benefit of RDFs production (B6). Combustibles are used as the raw materials to produce RDFs, furthermore other materials such as straws and limestone should be added and further processing of cutting, extrusion, shaping and transporting are needed. Therefore, benefit of producing RDFs was much less than directly generating electricity by incineration. The avoidance cost of post-closure care was usually ignored in assessing the benefit, but the benefit of avoidance of greenhouse gas emissions and leachate treatment (B8 + B9) could reach 2.70 million USD (10.9\% of the max. total benefit). Recycling metals and glasses could only result in a benefit of 0.18 million USD ( $0.7 \%$ of the max. total benefit) because the studied landfill used to be open to scavengers during its operation and the high quality recyclables had been removed before final disposal. The potential recycling benefits of this typical old landfill in China was much lower than many landfill mining projects of EU, and in some case in EU the metal recycling value was even one of the key drivers of the business case (Bosmans et al., 2013). The different compositions could explain the lower recycling value of metals in China, the metal contents in excavated waste from EU landfill were 1.1-2.8\% (Hogland et al., 2004; Jones et al., 2013; 


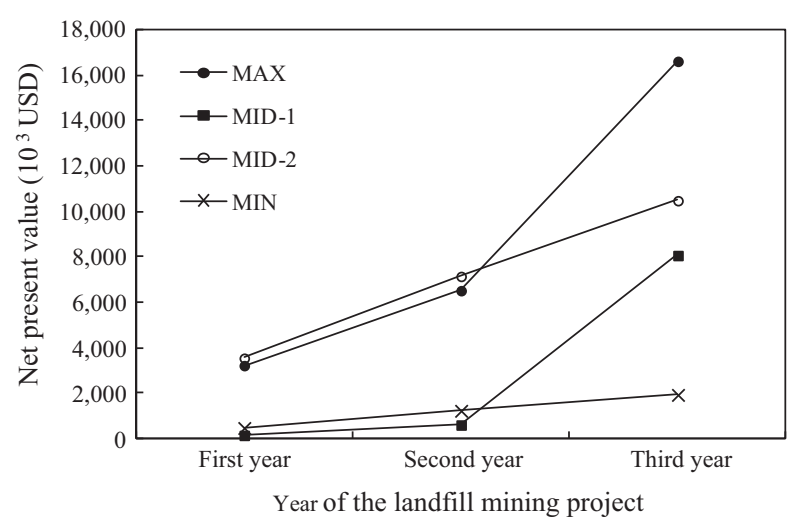

Fig. 6. Net present value for different project years under different scenarios.

Kaartinen et al., 2013; Quaghebeur et al., 2013), but in our case, the metal content was only $0.41 \%$. Moreover, large pieces of metals (copper, iron, aluminum, etc.), metal containers, PET plastic bottles, glass bottles were hardly found among the 22 waste samples of Yingchun landfill. Public or social benefits are also important in assessing feasibility of landfill mining projects, such as improving the urban landscape and the quality of ground water, building new parks on the old landfill, and increasing employment opportunities. Marella and Raga (2014) pointed out that the externalities should be taken into account for economic evaluation of landfill mining projects, in such a way that projects generating higher social benefits are not overlooked and can be favored through tailored policies and support schemes. Ayalon et al. (2006) studied the benefits from the engineering rehabilitation (i.e. prevent the underground water and air contaminations) and the benefits from the architectural-landscape rehabilitation of old landfills (i.e. convert the landfill to a park), and the findings reveal that the landfill remediation project will be economically feasible only if the benefits from architectural-landscape rehabilitation are taken into consideration.

\subsection{Comprehensive cost-benefit analysis}

The indicator of net present value (NPV) was adopted to evaluate the economic feasibility of the landfill mining project, and this project was planned to last three years. The NPV for the different project years in different scenarios is shown in Fig. 6. The NPV of all four scenarios was higher than 0 , indicating that the landfill mining project will result in a higher benefit than expected (social discount rate, $8 \%$ ). The NPV was sensitive to the benefits of land reclamation and electricity generation: for the MIN scenario, the NPV was only 1.92 million USD, and the NPV of MAX (16.63 million USD) was 8.66 times MIN. The benefit of electricity generation (B7) was the most important factor for each year's NPV, according to the results, and the NPV of scenarios MIN and MID-1 for the first and second years were much lower than those of MAX and MID-2.

The degree of urban development, extraction of supplementary waste fuel, recycling of materials and creation of new landfill spaces were found to be the main factors determining the feasibility of landfill mining (Hull et al., 2005; Bosmans et al., 2013). In this research, the land reclamation and energy recovery approaches were also the key factors of landfill mining. Moreover, the avoidance cost of post-closure care was found important and the metal recycling was found less important of this landfill mining project. If the reclaimed land is turned into natural area for public benefits (e.g. forest and grass land) after landfill mining, there will be a sharp decrease of private benefits for the landfill mining operator, and the NPV of scenario MIN will be 1.01 million USD. Differently from other categories of benefits such as land reclamation or material-energy recovery, it was sometimes difficult for the landfill mining project stakeholder to obtain the benefit from the avoidance cost of post-closure care. It is because of the uncertainty of obtaining financial support from the global clean development mechanism (CDM) market or the local government in charge of maintaining the old landfill. If this benefit cannot be obtained as expected, then the NPV will be less than 0 in scenario MIN, indicating that landfill mining would not be economically feasible any longer in that case. However, landfill mining has external effects that many stakeholders (incl. surrounding inhabitants, local government and local companies) benefit from but sometimes do not pay for (e.g. improving the urban landscape and the quality of ground water, building new parks on the old landfill, and increasing employment opportunities). There is a fundamental dilemma that the economic incentive will not be enough for private landfill mining operators, although the social or public benefits of landfill mining are huge. The external benefits should be quantitatively identified and transferred to visible profits by subsidies, tax remissions or other supportive policies to ensure the cost-benefit feasibility of landfill mining. According to previous researches, choice experiment (CE) was applied for assessing the external costs of landfill siting (Sasao, 2004), and contingent valuation method (CVM) was applied for assessing the external benefit of landfill mining and landfill rehabilitation (Ayalon et al., 2006; Marella and Raga, 2014). The methods of quantitatively assessing the external benefits need further studies to give scientific support for the policy makers, and the results of external benefits of landfill mining may be varied from different cases.

\section{Conclusion}

Assessing the economic feasibility and market potential is important for making decisions on landfill mining projects. A cost-benefit analysis model of landfill mining was applied and the market potential was assessed based on the field study. Among all of the costs and benefits of landfill mining, the greatest cost was that of rental excavation and hauling equipment, followed by the waste processing cost and the cost of material transportation; while the benefit of generating electricity by incinerating combustibles ranked first, followed by the benefit of land reclamation and then the benefit of recycling soil-like materials. Landfill mining will be cost-benefit effective considering the external and internal benefits, and the NPV was sensitive to the mode of land reclamation, the approach of energy recovery and the possibility of obtaining the benefits of avoiding postclosure care.

\section{Acknowledgments}

This research was financially supported by the National Natural Science Fund Committee of China (41201579, 71033005) and the Key Supporting Project of Ministry of Science and Technology of China (2012BAC13B04). This work was also partially supported by the Environmental Sanitation Agency of Jingmen City. Thanks are also due to Zhenfang Wang who helped us to complete this research and to the reviewers who helped to improve the paper.

\section{Appendix A}

(See Tables A1 and A2). 
Table A1

Capital and operational costs of the landfill mining project ( $1 \mathrm{USD}=6.2 \mathrm{CNY}$ ).

\begin{tabular}{|c|c|c|}
\hline Category of costs & $\begin{array}{l}\text { Costs } \\
\text { (million } \\
\text { USD) }\end{array}$ & Detailed information \\
\hline \multicolumn{3}{|l|}{ Capital cost } \\
\hline Site preparation (C1) & 0.06 & $\begin{array}{l}\text { Construction of } 3000 \mathrm{~m} \text { of protective netting and fencing, costing } 19.4 \text { thousand USD; maintenance of } 600 \mathrm{~m} \\
\text { of a flood-cutting ditch, costing } 38.7 \text { thousand USD }\end{array}$ \\
\hline $\begin{array}{l}\text { Rental or purchase of excavation and } \\
\text { hauling equipment (C2) }\end{array}$ & 2.53 & $\begin{array}{l}\text { Rent } 3 \text { excavators, } 6000 \text { USD per day; rent } 3 \text { tractor shovels, } 725.8 \text { USD per day; rent } 3 \text { trucks, } 725.8 \text { USD per } \\
\text { day; rent } 2 \text { lift trucks, } 387.1 \text { USD per day; } 300 \text { working days per year, including rental fees, labor costs and } \\
\text { diesel costs }\end{array}$ \\
\hline $\begin{array}{l}\text { Rental or purchase of screening and } \\
\text { sorting equipment (C3) }\end{array}$ & 0.36 & $\begin{array}{l}\text { An integrated facility with a drum screen, air classifier and magnetic separator was provided by Taiwan Tens } \\
\text { Corp. The price was } 1200 \text { thousand USD per set for a } 3 \text { year rental, with a } 10 \% \text { discount rate on capital assets }\end{array}$ \\
\hline $\begin{array}{l}\text { Construction or expansion of materials } \\
\text { handling facilities (C4) }\end{array}$ & 0.10 & $\begin{array}{l}\text { Material handling and storage up to } 1000 \mathrm{~m}^{2}, 56.5 \text { thousand USD; } 1200 \mathrm{~m}^{2} \text { cement concrete pavement, } 38.7 \\
\text { thousand USD }\end{array}$ \\
\hline \multicolumn{3}{|l|}{ Operational cost } \\
\hline Pre-activity research cost (C5) & 0.21 & $\begin{array}{l}\text { Cost of a feasibility study report, } 40.3 \text { thousand USD; exploration, investigation, and design of the landfill } \\
\text { mining project, } 96.8 \text { thousand USD; cost of the environmental impact assessment report, } 11.3 \text { thousands } \\
\text { USD; engineering cost computation, } 58.1 \text { thousand USD }\end{array}$ \\
\hline $\begin{array}{l}\text { Waste processing cost (excavation, } \\
\text { screening and sorting) (C6) }\end{array}$ & 2.26 & $\begin{array}{l}\text { Fresh water cost, } 0.16 \text { USD ton }^{-1} \text {; electricity cost, } 0.24 \text { USD ton }{ }^{-1} \text {; labor cost, } 1.45 \text { USD ton }^{-1} \text {; staff cost, } \\
1.45 \text { USD ton }^{-1} \text {; testing cost, } 0.06 \text { USD ton }^{-1} \text {; invisible cost, } 0.81 \text { USD ton }^{-1} \text {; total, } 4.18{\text { USD } \text { ton }^{-1} \text {, processing }}_{600 \text { ton waste per day }}\end{array}$ \\
\hline Transportation cost of materials (C7) & 0.81 & $\begin{array}{l}\text { The average transportation cost in Jingmen city was } 0.08 \text { USD ton }{ }^{-1} \mathrm{~km}^{-1} \text {; the average transportation } \\
\text { distance of soil-type materials, stones, glass and metals was } 15 \mathrm{~km} \text {; and the average transportation distance } \\
\text { of waste plastic, paper and wood was } 50 \mathrm{~km}\end{array}$ \\
\hline Final waste disposal cost (C8) & 0.03 & 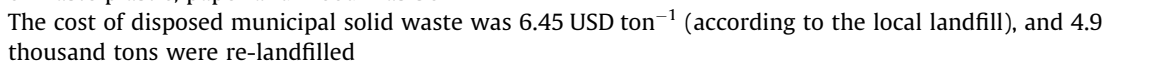 \\
\hline
\end{tabular}

Table A2

Comprehensive benefits of the landfill mining project ( $1 \mathrm{USD}=6.2 \mathrm{CNY}$ ).

\begin{tabular}{|c|c|c|}
\hline Category of benefit & $\begin{array}{l}\text { Benefits } \\
\text { (million } \\
\text { USD) }\end{array}$ & Detailed information \\
\hline \multicolumn{3}{|l|}{ Land and space reclamation } \\
\hline Benefit of regained lands (B1) & 8.23 & $\begin{array}{l}\text { Land price in the studied landfill was } 725.8 \text { thousand USD per hectare, and } 11.3 \text { ha of land was } \\
\text { reclaimed }\end{array}$ \\
\hline Benefit of recovered air-spaces (B2) & 0.98 & $\begin{array}{l}\text { A total of } 551 \text { thousand cubic meters of air-space were recovered that could be reused as a new } \\
\text { landfill, avoiding the cost of building affiliated facilities, with the benefit of air-space calculated as } \\
1.77 \mathrm{USD} \mathrm{m}^{-3} \text {, according to the national standard }\end{array}$ \\
\hline \multicolumn{3}{|l|}{ Recyclable materials recovery } \\
\hline $\begin{array}{l}\text { Recycling soil-type materials to organic fertilizer } \\
\text { and substrate(B3) }\end{array}$ & 3.64 & $\begin{array}{l}\text { Recycling soil-type materials for } 375.9 \text { thousand tons benefit the cover soil, nutrient soil or organic } \\
\text { fertilizer in the amount of } 9.68 \text { USD ton }{ }^{-1} \text { base on the contract of local flower planting companies } \\
\text { and the landfill mining operator }\end{array}$ \\
\hline $\begin{array}{l}\text { Recycling stones and construction waste to } \\
\text { regenerate construction materials (B4) }\end{array}$ & 0.05 & $\begin{array}{l}\text { Recycling } 41.4 \text { thousand tons of stones and construction waste provided a benefit of raw material } \\
\text { for regenerated construction materials in the amount of } 1.29 \text { USD ton }{ }^{-1} \text { according to our } \\
\text { investigations of local companies }\end{array}$ \\
\hline Recycling metal and glass (B5) & 0.18 & $\begin{array}{l}\text { Recycling } 2.1 \text { thousand tons of metals provided a raw material benefit of } 48.4 \text { USD } \operatorname{ton}^{-1} \text { according } \\
\text { to our investigations of local companies. Recycling } 3.2 \text { thousand tons of glass provided a raw } \\
\text { material benefit of regenerated glass in the amount of } 24.2 \text { USD ton }{ }^{-1} \text { according to our } \\
\text { investigations of local companies }\end{array}$ \\
\hline \multicolumn{3}{|l|}{ Energy recovery } \\
\hline $\begin{array}{l}\text { Producing residue derived fuels (RDFs) from waste } \\
\text { plastics (B6) }\end{array}$ & 0.89 & $\begin{array}{l}\text { Recycling } 73.6 \text { thousand ton of combustible waste (incl. plastic, paper, wood and textiles), the } \\
\text { benefit of raw materials for producing RDFs was } 12.1 \text { USD ton }{ }^{-1} \text {. It was determined by } \\
\text { investigations and interviews of local RDFs producing companies, and it was a average of accepted } \\
\text { price by the companies }\end{array}$ \\
\hline $\begin{array}{l}\text { Generating heat or electricity by incinerating } \\
\text { waste plastics or other combustibles (B7) }\end{array}$ & 10.12 & $\begin{array}{l}\text { Recycling } 73.6 \text { thousand tons of combustible waste, the heat transfer factor was } 95 \% \text {, the efficiency } \\
\text { of electricity generation was } 30 \% \text {, and the electricity price was } 0.54 \mathrm{USD} \mathrm{kWh}^{-1} \text {, minus the } \\
\text { incineration cost of } 24.2 \text { USD ton }\end{array}$ \\
\hline \multicolumn{3}{|l|}{ Avoidance cost of post-closure care } \\
\hline $\begin{array}{l}\text { Avoidance of leachate collection and treatment } \\
\text { (B8) }\end{array}$ & 0.32 & $\begin{array}{l}\text { Leachate production per day was } 80 \text { cubic meters, the average treatment cost was } 0.65 \text { USD m}^{-3} \text {; } \\
\text { the period requested for post-closure care was } 25 \text { years after the closure year of } 2004 \text { (17 years } \\
\text { after the starting year of landfill mining of } 2013 \text { ) }\end{array}$ \\
\hline Avoidance of landfill gas emission (B9) & 2.38 & $\begin{array}{l}\text { Calculating the landfill gas emissions with the China Landfill Gas Model provided by the US. EPA } \\
\text { (US-EPA, 2005), the potential emissions of landfill gasses from } 2013 \text { to } 2029 \text { was } 238 \text { thousand } \mathrm{CO}_{2} \\
\text { eq, and the benefit of avoidance of landfill gas emission was estimated by the value of the global } \\
\text { CDM market as } 10 \text { USD ton }{ }^{-1} \mathrm{CO}_{2} \text { eq }\end{array}$ \\
\hline
\end{tabular}

\section{References}

Ayalon, O., Becker, N., Shani, E., 2006. Economic aspects of the rehabilitation of Hiriya landfill. Waste Manage. 26, 13131323.

Bosmans, A., Vanderreydt, I., Geysen, D., Helsen, L., 2013. The crucial role of wasteto-energy technologies in enhanced landfill mining: a technology review. J. Clean. Product. 55, 1023.
GOSCC (General Office of the State Council of China), 2012. The Twelfth Five-Year Plan of Municipal Solid Waste Treatment Facilities of China. (in Chinese).

Hogland, W. Marques, M., Nimmermark, S., 2004. Landfill mining and waste characterization: a strategy for remediation of contaminated areas. J. Mater. Cycles Waste Manage. 6, 119124.

Hull, R.M., Krogmann, U., Strom, P.F., 2005. Composition and characteristics of excavated materials from a New Jersey landfill. J. Environ. Eng. 131, 478490. 
IWCS (Innovative Waste Consulting Services, US), 2009. Landfill Reclamation Demonstration Project: Perdido Landfill, Escambia County.

Jain, P., Townsend, T.G., Johnson, P., 2013. Case study of landfill reclamation at a Florida landfill site. Waste Manage. 33, 109116.

Jones, P.T., Geysen, D., Tielemans, Y., Van Passel, S., Pontikes, Y., Blanpain, B. Quaghebeur, M., Hoekstra, N., 2013. Enhanced landfill mining in view of multiple resource recovery: a critical review. J. Clean. Product. 55, 4555.

Joseph, K., Esakku, S., Nagendran, R., 2007. Mining of compost from dumpsites and bioreactor landfills. Int. J. Environ. Technol. Manage. 7, 317325.

Kaartinen, T., Sormunen, K., Rintala, J., 2013. Case study on sampling, processing and characterization of landfilled municipal solid waste in the view of landfill mining. J. Clean. Product. 55, 5666.

Krook, J., 2010. Urban and landfill mining: emerging global perspectives and approaches. J. Clean. Product. 18, 17721773.

Krook, J., Baas, L., 2013. Getting serious about mining the technosphere: a review of recent landfill mining and urban mining research. J. Clean. Product. 55, 19

Krook, J., Svensson, N., Eklund, M., 2012. Landfill mining: a critical review of two decades of research. Waste Manage. 32, 513520.

Marella, G., Raga, R., 2014. Use of the contingent valuation method in the assessment of a landfill mining project. Waste Manage. 34, 1199-1205.

MOHURD (Ministry of Housing and Urban-Rural Development of China), 2012. China Urban Construction Statistic Yearbook 2012. China Architecture and Building Press, Beijing (in Chinese).

Morelli, J., 1990. Landfill reuse strategies. Biocycle 31, 60-61.
Quaghebeur, M., Laenen, B., Geysen, D., Nielsen, P., Pontikes, Y., Van Gerven, T., Spooren, J., 2013. Characterization of landfilled materials: screening of the enhanced landfill mining potential. J. Clean. Product. 55, 7283.

Sasao, T., 2004. An estimation of the social costs of landfill siting using a choice experiment. Waste Manage. 24, 753762.

Savage, G.M., Golueke, C.G., Von Stein, E.L., 1993. Landfill mining: past and present BioCycle 34, 5861.

Singh, R.K., Datta, M., Nema, A.K., 2010. Review of groundwater contamination hazard rating systems for old landfills. Waste Manage. Res. 28, 97108.

Svensson, N., Frändegård, P., Krook, J., Eklund, K. 2010. Introducing an approach to assess environmental pressures from integrated remediation and landfil mining. In: Knowledge Collaboration \& Learning for Sustainable Innovation ERSCP-EMSU Conference, Delft, The Netherlands, October 25-29.

Taylor, R., Ray, R., Chapman, C., 2013. Advanced thermal treatment of auto shredder residue and refuse derived fuel. Fuel 106, 401409.

US-EPA, 1997. Landfill Reclamation (EPA 530-F-97-001). <http://www.epa.gov/ osw/nonhaz/municipal/landfill/land-rcl.pdf>.

US-EPA, 2005. Landfill Gas Emissions Model (LandGEM) Version 3.02.

Van der Zee, D.J., Achterkamp, M.C., de Visser, B.J., 2004. Assessing the market opportunities of landfill mining. Waste Manage. 24 (8), 795804.

Van Passel, S., Dubois, M., Eyckmans, J., de Gheldere, S., Ang, F., Tom Jones, P., Van Acker, K., 2013. The economics of enhanced landfill mining: private and societal performance drivers. J. Clean. Product. 55 (1), 92102.

Zhao, Y., Song, L., Huang, R., Li, X., 2007. Recycling of aged refuse from a closed landfill. Waste Manage. Res. 25 (2), 130138. 